\title{
The digital revolution and digitalized network society
}

\author{
Mark Knell ${ }^{1}$ (D)
}

Received: 24 July 2020 / Accepted: 18 January 2021/ Published online: 13 February 2021

(C) The Author(s) 2021

\begin{abstract}
This lecture discusses technological revolutions and techno-economic paradigms, but with an emphasis on the digital revolution and the digitalization of the economic and society. It draws its inspiration from works of Joseph Schumpeter, Christopher Freeman, and Carlota Perez on long waves of technological development and places the story within the context of global innovation networks. The lecture contends that the digital revolution not only transformed the world we live in but also created new ways to organize networks within it. We are now in second half of the digital (fifth technological) revolution, when the digitalization of the global networked economy prevails, and not at the beginning of Industrie 4.0. On the contrary, this is the period when economic growth drives the use of innovative digital technologies, including ubiquitous computing, robotics, and artificial intelligence, toward a truly digitalized network society.
\end{abstract}

Keywords Complexity · Innovation network · Techno-economic paradigm · Digital revolution

JEL classification $\mathrm{B} 25 \cdot \mathrm{B} 52 \cdot \mathrm{D} 85 \cdot \mathrm{F} 23 \cdot \mathrm{O} 31 \cdot \mathrm{O} 33$

\section{Introduction}

This lecture is about technological revolutions and techno-economic paradigms, but with an emphasis on the digital revolution and the digitalization of the economy and society. It is a story about the co-evolution of technologies and institutions through changes in actors and networks and the way they drive economic growth and development over extended periods of time (Nelson et al. 2018). And it is a story about evolutionary complexity, which involves many players, their collaborative networks, and their ability to take advantage of inter- and intra-network knowledge flows, as well as the various national and local institutional

Mark Knell

mark.knell@nifu.no

1 NIFU Nordic Institute for Studies in Innovation, Research and Education, PO Box 2815, Tøyen, 0608 Oslo, Norway 
arrangements within which the players relate (Kirman 2011; Frenken 2000). The lecture draws its inspiration from Schumpeter's vision of long waves (1939) and developed further by Knell $(2010,2013,2015)$ and then put in the context of global innovation networks. From the historical perspective, we know something about how the digital revolution and digitalization have transformed the economy and society over the past 50 years. Recent applications of these technologies have led to robotics, artificial intelligence, computerized algorithms, mobile sensors, 3D printing, and autonomous vehicles.

A techno-economic paradigm can have many diverse problem-solving activities contained within the paradigm. These trajectories of endogenous technological change are cumulative, incremental, and path-dependent by nature and describe the evolution of technological opportunities of a specific industry or technology (Nelson and Winter 1982, Dosi 1982). The digital revolution created new opportunities for technical change and technological learning for those industries that have access to relevant networks. Universal availability of the microprocessor, rapid growth in computing power (Moore's Law), and later extensive use in a wide variety of products and services both accelerated and enabled the growth of networked enterprise (Freeman and Louçã 2001). New forms of organization transformed the old Fordist paradigm into a digitalized network society, in which such networks matter not only for inter-personal communication but also for global innovation, R\&D collaboration, inventor networks, spatial innovation clusters (i.e., Silicon Valley), and global value chains.

The main idea of this paper is that the digital revolution not only transformed the world we live in but also created new ways to organize networks within it. While this idea is not new, it has recently become controversial because of the choice of theoretical argumentation. The notion of Industry 4.0 (Industrie 4.0 in German), for example, draws attention to the idea of industrial revolutions and its application to recent technologies, but it does not directly confront the ongoing theoretical debate on long waves and innovation networks. This article introduces a few of the basic ideas behind Industrie 4.0 and the Fourth Industrial Revolution and then discusses relevant issues in the work of Joseph Schumpeter, Christopher Freeman, and Carlota Perez on technological revolutions, long waves, and technoeconomic paradigms. A summary of the first four techno-economic paradigms follows, which brings us up to the digital revolution and the rise of digitalized network society. Then we ask: How do networks fit into our story, and what are global collaborative innovation networks? The paper then concludes by how we might envisage the future and the sixth industrial revolution.

\section{What is the fuss about Industrie 4.0}

Today, it is fashionable to write about Industrie 4.0 and the Fourth Industrial Revolution. The idea of Industrie 4.0 began as a marketing-style promotion by three engineers during a press conference at the Hannover Messe, a fair in Germany, in 2011. Two years later, the Federal Academy of Science and Engineering, with the support of the Federal Ministry of Research $(\mathrm{BMBF})$, presented a research agenda and implementation recommendations. This agenda became part of a specialized discourse meant to promote the digitalization of production and set up global innovation networks (GINs) that integrate machinery, warehousing systems, and production facilities through cyber-physical systems (Kagermann et al. 2013; Pfeiffer 2017). 
Since then, the term Industrie 4.0 has stimulated a lively, ongoing debate among the German public about the future of work and society.

Similar discourses on digitalization and automation technologies have taken place over the past decade. Rifkin (2011) claimed that we are at the beginning of a new industrial revolution where low-carbon energy generation technologies, such as wind, solar photovoltaic, hydropower, and wave and tidal power, lead the way. Brynjolfsson and McAfee (2014) argued that we are now in the second machine age in which intangible assets and productivity gains from digitalization of the economy intensified changes in skills, organizations, and institutions. They believe that earlier technologydriven revolutions, such as the steam engine and electrification, took longer to diffuse through the economy. Gordon (2016) then suggested that digitalization of the economy may have resulted to a productivity slowdown and increasing inequality.

The "Mastering the Fourth Industrial Revolution" became the motto of the 2016 World Economic Forum meeting in Davos, Switzerland. Schwab (2016), Schwab and Davis (2018) associated it with the diffusion of digital technologies and emerging technology breakthrough technologies such as biotechnology, nanotechnology, artificial intelligence, robotics, the Internet of Things, 3D printing, and quantum computing. We might describe these technologies as disruptive innovations in that they disrupt every industry in the global economy, leading to the transformation of entire systems of production, management, and governance. Schwab believed that technology and digitalization will revolutionize everything, generating major technological innovations that will fuel fundamental change that will spread throughout the global economy. He also suggests that a paradigm shift is currently underway. But there is no discussion of long waves, technological revolutions, and techno-economic paradigms, all of which are important for understanding Schumpeter or Industrie 4.0.

\section{Technological revolutions, long waves, and techno-economic paradigms}

Schumpeter $(1911 ; 1939)$ believed that major innovations and the diffusion of these breakthroughs initiate a fundamental change in the way things are produced, the types of new products, how a firm is organized (including new business models and new types of networks), and the way people transport things, network, and communicate. These innovations appear discontinuously in groups or swarms, causing a cyclical pattern of development that spread far beyond the original sector. Innovative entrepreneurs propel the evolution of the economy by creating "new combinations of existing resources" (Kurz 2012). So, Schumpeter defined innovation as the new combinations of new or existing knowledge that creates new products, markets, organizations, and production methods. The resulting clusters and networks of interrelated technological and organizational innovations create new and rapidly growing sectors, lead to structural change, and cause long swings in the economy. In Business Cycles, Schumpeter (1939) called these long waves Kondratieff cycles and then as "perennial gale[s] of creative destruction" for their transformational effect on the entire economy and society (Schumpeter 1942). ${ }^{1}$

\footnotetext{
${ }^{1}$ Schumpeter (1939) associated the term "industrial revolution" with the Kondratieff, referring to it 34 times in Business Cycles.
} 
Today, we think of technology as revolution and general purpose technologies (GPTs) as having a transformative effect on the entire economy and society. Here, innovation clusters appear as a series of interrelated radical breakthroughs, forming a constellation of interdependent technologies that reduce the cost of production over time. Schumpeter $(1934,223)$ did not expect innovations to appear "evenly distributed through time" but "discontinuously in groups or swarms," neglecting the cumulative effects of individually small innovations carried out over an extended period. Bresnahan and Trajtenberg (1995) reasoned that all GPTs have three key technological characteristics: pervasiveness, technological dynamism, and innovation complementarities. Lipsey et al. $(2005,98)$ define a GPT as "a single generic technology, recognizable as such over its whole lifetime, that initially has much scope for improvement and eventually comes to be widely used, to have many uses, and to have many spillover effects."

Freeman and Perez (1988), Freeman and Louçã (2001), and Perez (2002) saw these technological revolutions as techno-economic paradigms. They appear like a Kuhnian paradigm shift and are essential for guiding the interplay between technology, the economic structure, management, social institutions, and the way people relate to the technology. Perez (2002: 8) defined the techno-economic paradigm as "a powerful and highly visible cluster of new and dynamic technologies, products and industries, capable of bringing about an upheaval in the whole fabric of the economy." It is also "a set of interrelated radical breakthroughs, forming a major constellation of interdependent technologies," namely, "a cluster of clusters or a system of systems" (Perez 2010: 189). Perez $(2002,2010)$ also called the diffusion of techno-economic paradigms as "great surges of development" to differentiate them from Schumpeterian long waves.

A techno-economic paradigm has many diverse problem-solving activities within the paradigm itself. These technological trajectories are cumulative, incremental, and path-dependent by their nature and describe the evolution of technological opportunities of a specific industry or technology (Nelson and Winter 1982; Dosi 1982). For example, the digital revolution created new technological opportunities for the mechanization, specialization, and division of labor for those industries that have access to networks. Universal availability of the microprocessor, the rapid growth in computing power, and its later use in a wide variety of products and services accelerated and enabled the growth of networked enterprise (Freeman and Louçã 2001). New forms of organization transformed the mass production economy into a digitalized network society, in which networks matter not only for inter-personal communication but also for global innovation networks, R\&D networks, inventor networks, spatial innovation networks, and global value chains.

Every technological revolution follows an S-shaped diffusion pattern or technology life cycle. They originate in countries using core technologies and then spread to other economies, reaching the less developed regions as it diffuses through the global economy. Perez (2002) named four phases in each techno-economic paradigm: (1) irruption phase, when the modern technology supplants old technology; (2) frenzy phase, or the period of intense exploration; (3) synergy phase, when the new technology is diffused throughout the economy; and (4) maturity phase, as the diffusion process becomes complete. Each paradigm has a gestation period, in which a laboratory invention phase, with prototypes, patents, and early applications, will develop (Freeman and Louçã 2001), which can last for decades. The invention of the transistor 
in 1947 is a fitting example of an early application of digitalization. After a period of stagnation, a new paradigm will eventually assert itself.

A novel feature of Perez (2002) is that each techno-economic paradigm has a turning point where production capital displaces the financial capital. This idea follows from Schumpeter's recognition that the entrepreneur and financier are two independent economic agents that drive the innovation process. The financier dominates in the first two phases of the cycle, and the entrepreneur dominates in the second two phases. Financial bubbles are common just before the turning point as confidence in the financial system becomes more turbulent but support for the latest technology gains momentum. Substantial political unrest can also take place near the turning point. Stagnation combined with financial fragility appeared in the 1790s when Britain invested huge sums in canal building, during the 1840s railway mania in Britain and Ireland, during the panic of 1893 in the USA, in the 1929 stock market crash, and finally the in the financial collapse of 2007 in the USA. The entrepreneurial capital tends to dominate in the second phase, as the economy experiences strong productivity growth.

\section{From the industrial revolution to the digital revolution}

There have been five technological revolutions since Richard Arkwright introduced the first mechanical spinning machine, or water-frame, in a Cromford water-powered mill in $1771 .^{2}$ Table 1 summarizes the five technological revolutions. Each paradigm has its own all-pervasive low-cost input, usually a new source of energy or a new material, technologies, products and processes, and unique organization (Perez 2010; Knell 2013). The first column names the key energy source in each revolution, and the second column shows the first breakthrough. Columns three and four condenses the key physical and social technologies in each paradigm, which follows the broad distinction made by Nelson (2005). Physical technologies include the core technologies and leading industries, and social technologies are the institutional arrangements of the economy. The fifth column names key networks.

Timing is a key issue for long-wave theory. Schumpeter believed that Kondratieff long waves appear every 50 to 70 years and are reliant on the clustering of radical innovations. There are many ways to group the cycles. After Pavitt's (2000) taxonomy of innovative activities, Archibugi (2001) showed that each revolution resembled a distinct social technology. Schot and Kanger (2018) grouped the first four revolutions together as the first deep transition, differentiating it from the digital revolution. Brynjolfsson and McAfee (2014) called it the second machine age, as softwaredriven machines predominate. Industrie 4.0 named four stages of the industrial revolution: (1) water- and steam-powered mechanical manufacturing (first two long waves); (2) electrically powered mass production (second two long waves); (3) digitalization (fifth long wave); and (4) cyber-physical systems (sixth long wave) (Schwab and Davis 2018). We are currently in the second half of the fifth technological revolution.

\footnotetext{
${ }^{2}$ Precise dating of the first industrial revolution may be arguable, but both Schumpeter (1939) and Freeman and Perez (1988) recognize Richard Arkwright's patent on the water-frame in 1769. See also Knell (2010, 2013).
} 


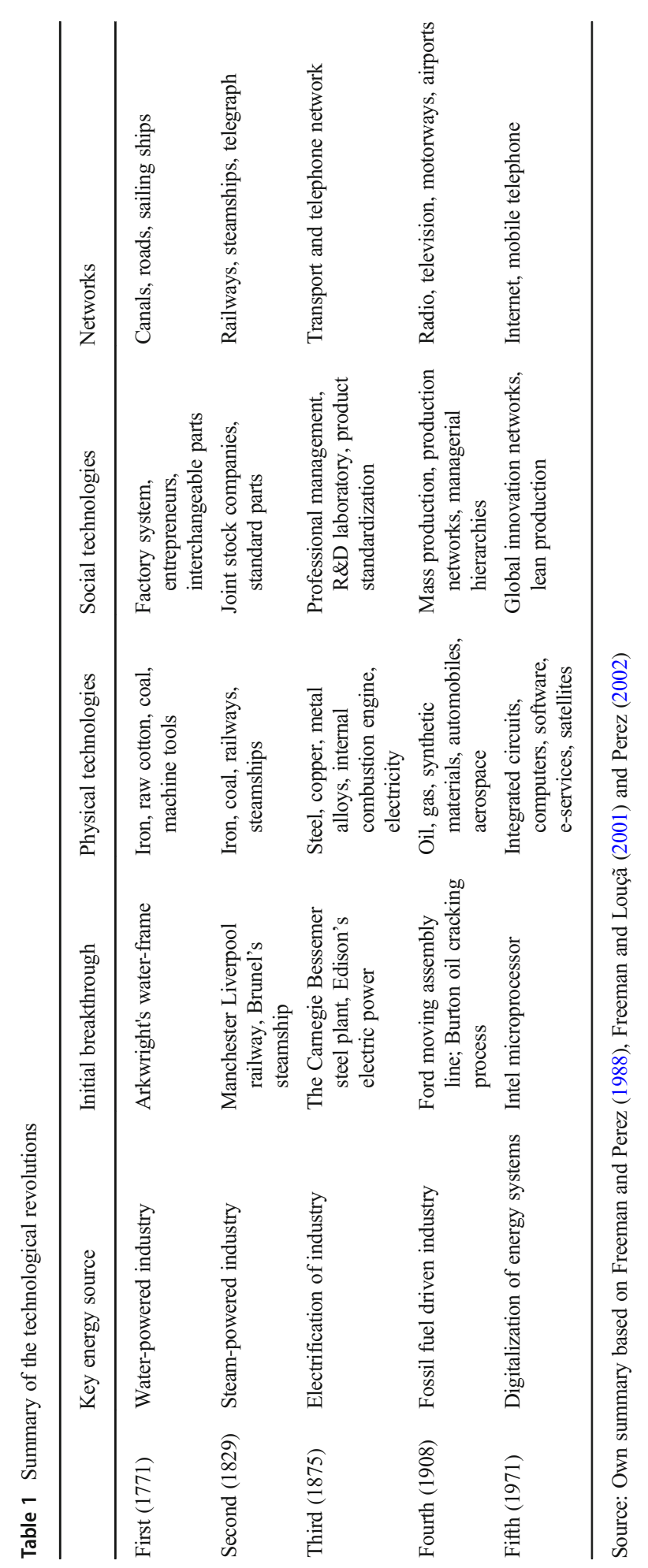


The First Technological Revolution marked the beginning of large-scale factory manufacturing and the specialization in tasks. Later refinements in milling and spinning technologies were key in the development of the machine tool industry. Falling prices and universal availability of wrought iron and the development of innovative metallurgical technologies stimulated the demand for many applications in the iron industry. Production networks remained local during this time, but the growth of turnpikes and canals encouraged the growth of cities and trade networks.

Innovation in the machine tool industry and in precision engineering gradually led to the design of smaller high-pressure steam engines. The Rainhill Locomotive trials and the opening of the Liverpool-Manchester between 1829 and 1831 marked the Second Technological Revolution. As resource prices fell, steam-powered mechanization of industry became the key technology (Chandler 1977). Agglomeration, standardization, and specialization accelerated productivity growth during this time. Railways, telegraphs, transatlantic steamship navigation, and a universal postal service also made it possible to network the economy. Patent data shows that collaborative inventor networks and innovation networks were key in the USA during this time in textiles, clocks, and printing (Thomson 2009).

The Third Technological Revolution started the electrification of industry, transport, and a new electrical equipment industry from 1875. Innovative technology also made steel inexpensive. Steel, chemicals, copper, and other metal alloys were key for the development of shipping, railways, bridges, tunnels, and other large civil engineering projects. Thomas Edison created the first professional research and development (R\&D) laboratory, with the explicit aim to provide the market with steady stream of new products, which later included the phonograph, microphones, electric lighting, and a system for electrical distribution, as well as other goods (Isreal 1998). This made it easier to recombine old ideas in new ways and to encourage the creation of social networks both within and outside the laboratory.

Cheap oil, because of its abundance and declining prices, combined with the Ford moving assembly line in 1913, made it possible to produce inexpensive motorized vehicles. This application of mass production techniques was essential to the Fourth Technological Revolution, including making use of machines and presses to stamp out parts and ensure interchangeability, which led to the relative cheapness of large-scale production and the emergence of mass consumption (Hounshell 1984). Many industries appeared using mass production techniques, including automotive components, tractors, aircraft, consumer durables, and synthetic materials, to ensure that mass consumption continued (Freeman and Louçã 2001). After the Second World War, the USA and Europe experienced extended periods of high growth (mass production, mass consumption, and resource intensity), innovative product design, and intensive positive feedback effects. This led to the creation of even larger corporations that required new ways of managing diverse operations (Chandler 1977).

\section{Digitalization, technological trajectories, and the digitalized network society}

The digital revolution was bubbling underneath the fourth industrial revolution. Advances in the vacuum tube (1935) and transistor (1947), followed by many prototypes, 
patents, and early applications at Bell Labs, anticipated the digital revolution. A vibrant electronic cluster then appeared in the Santa Clara (Silicon) Valley (Lécuyer 2006). In 1969, Intel announced plans to make the first commercially practical (4004) microprocessor out of silicone (realized in November 1971), the same year the US department of defense installed the first computers on ARPANET (which later morphed into the Internet). This microprocessor made it possible to incorporate all the functions of a central processing unit (CPU) onto a single integrated circuit. The Apollo Guidance Computer was the first silicon integrated circuit-based computer, which led to the microprocessor (Isaacson 2014). This was the big bang of the digital revolution!

The microprocessor was a revolutionary breakthrough. Although the original Intel microprocessor had only 2250 transistors, the number of transistors in an integrated circuit doubled about every 2 years (Moore's Law). Soon afterwards, several new technological trajectories appeared within the digital techno-economic paradigm, which evolved into clusters of new and dynamic technologies, products, and industries that rippled through the entire economy and society. New enterprises appeared and interacted with each other in complex networks, which perused problem-solving activities that were cumulative, incremental, and path-dependent (Arthur 2014). This led to the development of a global digital telecommunications network and the Internet, together with electronic mail and other e-services. By 2020, Apple had made an innovative a 5 -nm processor with 11.8 billion transistors that easily fit inside an iPhone.

We are now in the second half of the digital revolution. The financial collapse of 2008 marked the turning point, as power shifted away from financiers to entrepreneurs and enterprises, and currently we should be in the period of high economic growth, or the golden age. Here diffusion is key, as is the complete digitalization of everyday objects and activities, or what we might refer to as ubiquitous computing (Weiser 1991). A wide array of new products dependent on microprocessors have appeared in recent decades, including robotics, artificial intelligence (AI), and smart energy networks (Perez 2013; Knell 2013). Modern robots can be autonomous or semi-autonomous, appearing human-like at times, but most often they are just a complex industrial machine with little guiding intelligence. These included industrial robots, warehouse robots, agricultural robots, autonomous vehicles, caring robots, medical robots, and robots in education (Hudson 2019). A few robots have AI, but that are narrow and limited by the inability to deal with common sense solutions to everyday problems (Mitchell 2019).

\section{How do networks fit into our story?}

Innovation networks have existed in one form or another for a long time. Rome developed and controlled trade and communication networks throughout the Mediterranean, which later spread throughout much of Europe. As the Roman Empire evolved, both the size and intensity of commercial and trading networks increased, as did the speed and direction of technological change and specialization (Kay 2014). After the decline of the Roman Empire, a set of complex trading and merchant banking networks appeared in Roman Italy that extended beyond the Mediterranean and Middle East (Spufford 1988). English merchants secured commercial alliances and solidified trade routes and networks in the late fourteenth century (Games 2009). At the same time, commercial networks also intersected with social networks in Hansa towns and 
supported communities, which then coincided with the development of modern technologies within the network (Ewert and Selzer 2016). The example of woollen coat manufacturing in Adam Smith illustrates the diversity of different tasks and technologies required to make a coat at the beginning of the industrial revolution.

Before the industrial revolution, local producers made clothing and tools using local materials. National production networks were important for engine builders, as they improved machine tools, casting, and measurement techniques from other sectors after the industrial revolution (Thomson 2009). Improved waterwheels and the growth of turnpikes, canals, and other waterways also led to the expansion of trade networks, but production networks remained local. Advancements in steam engine technology replaced water-powered technologies, and railways, telegraphs, transatlantic steamship navigation, and a universal postal service made it possible to network the economy (Chandler 1977). As steamships (shipping) and railways advanced, electricity and telephone networks then appeared. This gave rise to global trading networks and empires, which relied on telegraphs and telephones for coordination. Networks of roads, highways, ports, and airports as well as networks of oil ducts became essential in the Fourth Technological Revolution. Global production networks and multinational enterprises then appeared, making it possible to have both inter-firm and intra-firm trade and production.

Smith supplied the essential building blocks underlying the complex innovation network (Arthur 2014). The idea that cooperative production increases productivity was one of his great insights. In the Wealth of Nations, Smith (1776) used a recursive loop to explain how a more sophisticated division of labor could lead to higher labor productivity through the improvement in the dexterity of workers, saving time lost in switching between different tasks, and the introduction of new machines and forms of organization. Alfred Marshall (1920) later pointed out that the increased specialization of labor and differentiated knowledge appears as economies external to the enterprise. Benefits from these externalities can come directly through collaborative networks with other innovators or indirectly through spillovers. Penrose (1959) later explained how certain strategic capabilities within enterprises encouraged them to pool resources with other firms and organizations to access knowledge complementary to their own knowledge base. ${ }^{3}$ Richardson (1972: 888) then reasoned that firms "are linked together in patterns of co-operation and affiliation" and that "inter-firm co-operation is concerned very often with the transfer, exchange or pooling of technology (892)." Inspired by Simon (1969), Nelson and Winter (1982) consider firms to be complex networks of routines and decision rules. These examples of increasing returns originate from network externalities or other positive feedback mechanisms (Arthur 1994).

One distinctive characteristic of the digital revolution is the rise of global production networks (Coe and Yeung 2015), GINs (Zander 2002), global R\&D networks (Tomasello et al. 2016), global inventor networks (Graf 2012, Fritsch and Zoellner 2020), user innovation networks (von Hippel 2007), and spatial innovation networks (i.e., Silicon Valley). The rise of the digital economy parallels the growth of a networked society. As the digital revolution unfolded, the digitalization of the economy accelerated networking and information exchange as well as encouraged international

\footnotetext{
${ }^{3}$ Penrose (1959) considered knowledge to be the most strategic resource of the firm, while Wernerfelt (1984) sees knowledge as a generic resource covering all assets, capabilities, and competencies. Von Tunzelmann (2009) distinguished between technological (and dynamic) capabilities and competencies.
} 
outsourcing and offshoring (Meijers et al. 2008). Internationalization of R\&D activities accelerated as global enterprises located their R\&D activities outside their home country over the past 50 years. And it would be interesting to know about the longterm evolution of inventor networks (Kudic et al. 2020). The trend towards globalization of innovation is part of a general tendency of firms to source technology externally and to collaborate with other firms, universities, and public research organizations, which comes in addition to internal investments in R\&D and innovation activities (Freeman 1991; Powell and Ginnaella 2010; Hanaki et al. 2010). As already mentioned, internal, local, and global innovation networks are key social technologies in the digital revolution. This is where we focus our attention.

\section{What are global innovation networks?}

GINs are essential for the creation, transfer, and absorption of new knowledge and economic growth in the digital revolution. Freeman (1991) contended that the development of new products and processes depend on external information networks and collaboration with users. Collaboration is important because it reduces the risk and complexity involved in the development of new products and processes by spreading it among several geographically dispersed partners with agreed complementary aims (Hagedoorn 1993). It often entails the development and acquisition of new capabilities, as each agreement involves a shared commitment of resources and knowledge and encourages interactive learning. Collaborative agreements between firms and other organizations appear in the formalized links or global networks in which individual firms work and may include agreements within an enterprise group, upstream suppliers, downstream customers, competitors, the government, and universities and other research institutes. These agreements can be formal and rigid, usually encompassing a collaborative agreement or strategic alliance with long-term aims, or they can be informal, flexible, and trust-based relations, often linking enterprises with various local actors (Freeman 1991, DeBresson and Amesse 1991; Powell and Grodal 2005). ${ }^{4}$ The form of ownership, the location of a partner within the network, and the strength of ties between partners can have important consequences (Granovetter 1973).

GINs make it possible to transcend national boarders, but they do not replace the institutional arrangements that support the national innovation system. Ernst (2009), and Barnard and Chaminade (2011) define a GIN as a global network of interconnected and integrated functions and operations carried out by firms and non-firm organizations engaged in the creation or diffusion of innovations across geographic borders. Global value chains that include engineering, product development, and research activities often appear alongside a GIN. GINs form because enterprises need certain kinds of technical knowledge; they are unable to generate for themselves (Ahuja 2000). This in turn creates new "opportunities for linking flexible specialization across the boundaries of firms, and for triggering continuous interactive innovation" (Imai and Baba 1991).

\footnotetext{
${ }^{4}$ Freeman (1995) also emphasized the continued influence that the system of innovation, local research and scientific organizations, public policy, and other national institutional arrangements have on the national economy. Archibugi and Michie (1997) introduced the terms techno-nationalism and techno-globalism. Carlsson (2006) suggests that the national innovation systems themselves are becoming internationalized.
} 
Large multinational enterprises often plan global networks on a large scale. These firms coordinate production, marketing, and $\mathrm{R} \& \mathrm{D}$ activities from one central location, but these activities are carried out in locations throughout the world. Other global networks evolve in a self-organizing way. These have individual collaborative agreements that aid cooperation through technology cross-licensing, outsourcing, joint ventures and R\&D agreements, and other types of innovative activities (Pyka 1997; Rycroft and Kash 2004). The institutional arrangements of the national innovation system set the rules of the game for each location, or node, within the innovation network. Innovation networks often form because enterprises need certain kinds of technical knowledge as they are unable to generate themselves, but they also reflect existing relationships and network capabilities.

There are many different varieties of collaborative arrangements. Narula (2003) described how they vary from wholly owned subsidiaries with full internalization of transaction, across various types of equity and non-equity agreements, to spot market transactions, where independent firms engage in arms-length transactions. Powell and Grodal (2005) emphasized the importance of informal-non-contractual innovation cooperation, such as common membership in a professional or trade association, participation in ad hoc industry committees, or executive education programs, conferences, mobility, common educational backgrounds, etc. (Freeman 1991; Pyka 1997). ${ }^{5}$ The distinction of organizational modes of innovation cooperation is also important since they produce different impacts on participating firms' innovation activity. Granovetter $(1973,1983)$ explained how weak ties serve more as bridges to novel information where there is a rapid exchange, while strong ties are useful for social control and the exchange of tacit knowledge.

While GINs are not new, digitalization of the economy has encouraged the development of GINs, as it helped the organization and planning of innovative activities. There are several types of innovation networks that involve enterprises collaborating with each other or with other organizations. DeBresson and Amesse (1991) identify at least five different types of innovation networks: supplier-user networks, networks of pioneers and adopters within the same industry, regional inter-industrial networks, international strategic technological alliances in new technologies, and professional inter-organizational networks that develop and promote new technologies. Tidd (2006) developed a typology of innovation networks: new product or process development consortium to share knowledge and perspectives; sectoral forum to adopt and develop good innovative practice; new technology development consortium to share knowledge on newly emerging technologies; emerging standards around innovative technologies; supply chain learning by sharing innovative good practice and possibly shared product development; clustering to exploit innovation synergies; and topic network to explore new technologies (Nonaka et al. 2000).

Innovation networks can be more formal and ridged, usually encompassing a collaborative agreement or strategic alliance with long-term objectives, or they can be informal, flexible and trust-based relations, often linking enterprises with various local (Camagni 1991) and regional (Boschma 2005) actors, as Lundvall and Borràs (1998) contend. They often form, as Ahuja (2000) points out, because enterprises need

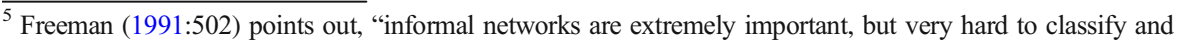
measure."
} 
certain kinds of technical knowledge, they are unable to generate themselves, or as Imai and Baba (1991) suggest, for triggering continuous interactive innovation. Granovetter (1983) suggest that innovation networks are path-dependent, often reflecting existing relationships and network capabilities. Pittaway et al. (2004) claim that firms generally benefit from being part of an innovation network by sharing the risk and uncertainty intrinsic to the innovation process, gaining access to access to new markets and technologies, speeding up the process of bringing new products to market, pooling complementary skills, protecting property rights when incomplete contracts, and providing access to external knowledge embedded in local social networks (Cohen and Levinthal 1989).

Imai and Baba (1991) suggest three strategies that underlie GINs. One strategy, called the traditional multi-domestic network, is typical of the traditional manufacturing industries, which rely heavily on technology coming from suppliers of equipment and materials. The second strategy, called the globalization strategy, includes planned internalization by multinational enterprises, which consider their market to be global, but try to coordinate production, marketing, and R\&D activities from a central decision-making system. Innovation networks of this kind are organized by a multinational enterprise, with both weak and strong connections between constituent members, which may or not be a wholly owned affiliate. A third strategy involves self-organizing networks, which have joint ventures, collaborative agreements, and long-term cooperation that includes cross-licensing, outsourcing, joint R\&D, and other types of innovative activities (Pyka 1997, Pyka and Scharnhorst 2009, Kirman 2011).

Dittrich (2004) argues that GINs can be either open or closed. In a closed interconnected network, with norms and sanctions well understood, knowledge flows freely between enterprises. Path dependencies tend to focus its member on preserving existing capabilities of the firm. Enterprise in an open interconnected network extensively results in a wide range of competencies across its members but also creates more opportunities for reaching new technological capabilities. There is some controversy over which kind of innovation network works best or whether they can lead to network failure. ${ }^{6}$ Coleman (1988) suggests that closed networks tend to encourage innovation more than open networks, whereas Burt (1992) suggests that firms should strive to position themselves strategically in gaps between different nodes, so as to become intermediaries, rather than maximizing the number of ties. Shan et al. (1994) suggest that the number of collaborative relationships that a firm is involved in is positively related to innovation output, while Ahuja (2000) shows that improving trust and reducing opportunism creates more cohesive interconnected partners.

The growth of GINs over the digital revolution also reflects the internationalization of $R \& D$ activity. Statistics indicate that there has been an increase of international funding of business R\&D, firms increasingly collaborate across borders in R\&D and innovation activities, increased numbers of $\mathrm{R} \& \mathrm{D}$ subsidiaries are set up abroad by multinational enterprises, and increased numbers of patents are filed by co-inventors in different countries (Iversen et al. 2017; Knell 2017). As the costs and complexity of

\footnotetext{
${ }^{6}$ Von Tunzelmann (2004) maintains that network failure or misalignment can also happen if there is general lack of network capabilities, which may include a lack of scale, inter-firm conflict, external disruption too little trust between partners, too much opportunism, or a lack of infrastructure. Network relationships with suppliers, customers, and intermediaries are key factors that affect productivity growth and innovation.
} 
$R \& D$ increase, enterprises tend to internationalize and digitalize their activities at earlier stages of their life cycle.

We also know that half of all production happens within GINs. Here the digitalization of the vertical production system complements the horizontal networking across the entire value chain, ranging from suppliers and business partners to customers. Global value chains (GVCs) appear as physical transfers of goods and services across borders, which make it possible to measure the sequences of value added within an industry, from conception to production and end use. This requires multiple firms to carry out these activities in various locations (Frederick 2019). Technology upgrading appears as a change from lower to higher value-added activity or moving up the global value chain (or climbing the quality ladder). Skill upgrading is often associated with offshoring, which often leads to intra-industry trade (Grossman and Rossi-Hansberg 2008). ${ }^{7}$ We associate it with a nation's competencies and patterns of specialization. Technology upgrading can appear in factories, inter-firm networks, local or national economies, and regions (Gereffi 2018), as well as new methods of production and organization (process upgrading), new more complex products (product upgrading), new and higher valueadded activities (functional upgrading), and the adaptation of competencies to a new industry (intersectoral upgrading) (Humphrey and Schmitz 2002).

\section{Anticipating the future}

Can we envisage the future and the sixth industrial revolution? Possible emerging technologies include nanotechnology, biotechnology, quantum computing, and AI. This is where the physical, digital, and biological worlds could converge. Inspiration for the idea appeared in Richard Feynman 1960 lecture, "There's Plenty of Room at the Bottom." Feynman described a process in which scientists would be able to manipulate and control individual atoms and DNA molecules. The idea of the transistor and the microprocessor started the process of miniaturization. Feynman predicted nanoscience and nanotechnology, which became the study and application of extremely tiny things. We can apply these things across all the other science fields, such as chemistry, biology, physics, materials science, and engineering. Here, we can tie the digital revolution to the sixth technology revolution or long wave.

It is possible that two or three independent technological systems could converge into one system, which would then trigger the explosive take-off into the sixth technological revolution. Atoms, DNA, bits, and synapses may supply the basic elements and foundational tools that will make it possible to integrate several emerging technologies, including nanotechnology, biotechnology, information technology, and the latest cognitive technologies, into multifunctional systems (Roco and Bainbridge 2003). Over time nanotechnology may improve productivity, reduce costs, new infrastructures, and encourage the creation of new products and processes using nanomaterials (Knell 2010).

Anticipating a future involves changing the techno-economic paradigm. Are we ready for the age of the quantum? Will modern microscopy lead the way? Will we see a

\footnotetext{
$\overline{7}$ Offshoring involves foreign direct investment (FDI), while international outsourcing occurs through trade and arm's length market transactions.
} 
convergence across a range of disciplines in anticipation of the sixth industria 1 revolution? Will the manipulation of DNA molecules and the rearrangement of atoms reorganize our societies, our values, the economy, and the environment as well? What role will networks play in the new economy? These kinds of questions are essential for developing a better understanding of the future. The anticipatory systems view makes it possible to integrate the future into the present by formulating diverse ways and several reasons for thinking about the future (Miller 2018). Traditional foresight models cannot predict novelty, disruption, complexity, or a shift in paradigms with great certainty. But it is possible to use the future to identity challenges and opportunities and to discuss systemic transformations. This requires a new framework for connecting the theories and practices of "using-the-future" and appreciating complexity and the role that networks play.

Acknowledgments The author would like to thank Per Koch and Muhamed Kudic as well as the participants in the 5th RA [X] 'Networks" Workshop held on 21-22 November 2019 in Stuttgart, Germany. The usual caveats apply.

Open Access This article is licensed under a Creative Commons Attribution 4.0 International License, which permits use, sharing, adaptation, distribution and reproduction in any medium or format, as long as you give appropriate credit to the original author(s) and the source, provide a link to the Creative Commons licence, and indicate if changes were made. The images or other third party material in this article are included in the article's Creative Commons licence, unless indicated otherwise in a credit line to the material. If material is not included in the article's Creative Commons licence and your intended use is not permitted by statutory regulation or exceeds the permitted use, you will need to obtain permission directly from the copyright holder. To view a copy of this licence, visit http://creativecommons.org/licenses/by/4.0/.

\section{References}

Ahuja G (2000) The duality of collaboration: inducements and opportunities in the formation of interfirm linkages. Strateg Manag J 21:317-343

Archibugi D (2001) Pavitt's taxonomy sixteen years on: a review article. Econ Innov New Technol 10(5):415425

Archibugi D, Michie J (1997) Technological globalisation or national systems of innovation. Futures 29:121137

Arthur WB (1994) Increasing returns and path dependence in the economy. University of Michigan Press, Ann Arbor

Arthur WB (2014) Complexity and the Economy. Oxford University Press, Oxford

Barnard H, Chaminade C (2011) Global innovation networks: towards a taxonomy, WP 2011/04, Centre for Innovation, Research and Competence in the Learning Economy (CIRCLE). Lund University

Boschma R (2005) Proximity and innovation: a critical assessment. Reg Stud 39(1):61-74

Bresnahan TF, Trajtenberg M (1995) General purpose technologies 'Engines of growth'? Journal Econom 65(1):83-108

Brynjolfsson E, McAfee A (2014) The second machine age. Work, progress, and prosperity in a time of brilliant technologies. W.W. Norton, New York

Burt RS (1992) Structural holes: the social structure of competition. Cambridge University Press, Cambridge

Camagni R (ed) (1991) Innovation networks: spatial perspectives. Belhaven Press, London

Carlsson B (2006) Internationalization of innovation systems: a survey of the literature. Res Policy 35:56-67

Chandler AD Jr (1977) The visible hand. Harvard University Press, Cambridge

Coe NM, Yeung HWC (2015) Global production networks: theorizing economic development in an interconnected world. Oxford University Press, Oxford

Cohen WM, Levinthal DA (1989) Innovation and learning: the two faces of R\&D. Econ J 99:569-596

Coleman JS (1988) Social capital in the creation of human capital. Am J Sociol 94:S95-S120 
DeBresson C, Fernand A (1991) Networks of innovators: A review and introduction to the issue. Res Policy 20(5):363-379

Dittrich K (2004) Innovation networks: exploration and exploitation in the ICT industry. Druk, Rotterdam

Dosi G (1982) Technological paradigms and technological trajectories. Res Policy 11:147-162

Ernst D (2009) A new geography of knowledge in the electronics industry?, Policy Studies, No. 54. East-West Center, Honolulu

Ewert UC, Selzer S (2016) Institutions of Hanseatic trade studies on the political economy of a medieval network organisation. Peter Lang, Frankfurt

Feynman RP (1960) There's Plenty of Room at the Bottom. Engineering and Science 23:22-36

Frederick S (2019) Global value chain mapping. In: Ponte S, Gereffi G, Gale Raj-Reichert G (ed.) Handbook on Global Value Chains. Edward Elgar Publishing pp. 29-53

Freeman C (1991) Networks of innovators: a synthesis of research issues. Res Policy 20:499-514

Freeman C (1995) The 'national system of innovation' in historical perspective. Camb J Econ 19:5-24

Freeman C, Louçã F (2001) As time goes by from the industrial revolution to the information revolution. Oxford University Press, Oxford

Freeman C, Perez C (1988) Structural crisis of adjustment, business cycles and investment behaviour. In: Dosi G, Freeman C, Nelson R, Silverberg G, Soete L (eds) Technical Change and Economic Theory. Pinter, London

Frenken K (2000) A complexity approach to innovation networks: the case of the aircraft industry (19091997). Res Policy 29:257-227

Fritsch M, Zoellner M (2020) The fluidity of inventor networks. J Tech Tran 45:1063-1087

Games A (2009) The web of empire English cosmopolitans in an age of expansion 1560-1660. Oxford University Press, Oxford

Gereffi G (2018) Global value chains and development. Cambridge University Press, Cambridge

Gordon RJ (2016) The rise and fall of American growth: the U.S. standard of living since the Civil War. Princeton University Press, Princeton

Graf H (2012) Inventor networks in emerging key technologies: information technology vs. semiconductors. J Evol Econ 22:459-480

Granovetter MS (1973) The strength of weak ties. Am J Sociol 78:1360-1380

Granovetter MS (1983) The strength of weak ties: a network theory revisited. Sociological Theory 1:201-233

Grossman GM, Rossi-Hansberg E (2008) Trading tasks: a simple theory of offshoring. Am Econ Rev 98(5): 1978-1997

Hagedoorn J (1993) Understanding the rational of strategic technology partnering - organizational modes of cooperation and sectoral differences. Strateg Manag J 14(5):371-385

Hanaki N, Nakajima R, Ogura Y, Y. (2010) The dynamics of R\&D network in the IT industry. Res Policy 39(3):386-399

Hounshell DA (1984) From the American System to Mass Production, 1800-1932: The Development of Manufacturing Technology in the United States. Johns Hopkins University Press, Baltimore

Hudson J (2019) The robot revolution: understanding the social and economic impacts. Edward Elgar, Cheltenham

Humphrey J, Schmitz H (2002) How does insertion in global value chains affect upgrading in industrial clusters? Reg Stud 36(9):1017-1027

Imai K, Baba Y (1991) Systemic innovation and cross-border networks: transcending markets and hierarchies to create a new techno-economic system. In: Technology and Productivity: The Challenge for Economic Policy. OECD, Pari, pp 389-405

Isaacson W (2014) The innovators: how a group of hackers, geniuses, and geeks created the digital revolution. Simon \& Schuster, New York

Isreal P (1998) Edison: a life of invention. John Wiley, New York

Iversen E, Dachs D, Poti B, Patel P, Cerulli G, Spallone R, Zahrandnik G, Knell M, Scherngell G, Lang L (eds) (2017) Internationalisation of business investments in R\&D and analysis of their economic impact (BERD Flows): final Project Report. European Commission, Brussels

Kagermann H, Wahlster W, Helbig J (2013) Recommendations for implementing the strategic initiative INDUSTRIE 4.0: final report of the Industrie 4.0 Working Group, April 2013

Kay P (2014) Rome's economic revolution. Cambridge

Kirman A (2011) Complex economics: individual and collective rationality. Routledge, London

Knell M (2010) Nanotechnology and the sixth technological revolution. In: Cozzens S, Wetmore J (eds) Nanotechnology and the challenges of equity, equality and development. Springer, Netherlands, Heidelberg

Knell M (2013) Multi-source energy networks and the ICT revolution. Eur Plan Stud 21:1838-1852 
Knell M (2015) Schumpeter, Minsky and the financial instability hypothesis. J Evol Econ 25:293-310

Knell M (2017) R\&D internationalisation and local innovation in the Visegrad Group after the FDI peak. In: Galgóczi B, Drahokoupil J (eds) Condemned to Be Left behind? Can Central and Eastern Europe Emerge from Its Low-Wage Model? European Trade Union Institute, Brussels, pp 111-131

Kudic M, Fritsch M, Mueller M (2020) Long-term evolution of inventor networks. Exploring the origins of structural change processes along different analytical levels. Under review.

Kurz HD (2012) Schumpeter's new combinations. J Evol Econ 22(5):871-899

Lécuyer C (2006) Making Silicon Valley: innovation and the growth of high tech, 1930-1970. MIT Press, Cambridge

Lipsey RG, Carlaw KI, Bekar CT (2005) Economic transformations: general purpose technologies and long term economic growth. Oxford University Press, Oxford

Lundvall B-Å, Borràs S (1998) The globalising learning economy: implications for innovation policy. European Commission: http://www.cordis.lu/tser/src/globec.htm.

Marshall A 1920 [1961]. Principles of Economics, [9th variorum edition, C.W. Guillebaud, ed.] London: Macmillan.

Meijers H, Dachs B, Welfens PJJ (eds) (2008) Internationalisation of European ICT activities: dynamics of information and communications technology. Springer-Verlag, Berlin

Miller R (2018) Transforming the future: anticipation in the 21st Century. Routledge, London

Mitchell M (2019) Artificial intelligence: a guide for thinking humans. Pelican Books, London

Narula R (2003) Understanding the growth of international R\&D alliances. In: Cantwell J, Molero J (eds) Multinational enterprises, innovative strategies and systems of innovation. Edward Elgar, Cheltenham

Nelson RR (2005) Technology, institutions, and economic growth. Harvard University Press, Cambridge, MA

Nelson RR, Winter SG (1982) An evolutionary theory of economic change. Harvard University Press, Cambridge, MA

Nelson R, Dosi G, Helfat C, Pyka A, Saviotti PP, Lee K, Winter SG (2018) Modern evolutionary economics an overview. Cambridge University Press, Cambridge

Nonaka I, Toyama R, Nagata A (2000) A firm as a knowledge-creating entity: a new perspective on the theory of the firm. Ind Corp Chang 9:1-20

Pavitt K (2000) Technology. Management and system of innovation. Edward Elgar, Cheltenham

Penrose E (1959) The theory of the growth of the firm. Oxford University Press, Oxford

Perez C (2002) Technological revolutions and finance capital: the dynamics of bubbles and golden ages. Edward Elgar, Cheltenham

Perez C (2010) Technological revolutions and techno-economic paradigms. Camb J Econ 34(1):185-202

Perez C (2013) Unleashing a golden age after the financial collapse: drawing lessons from history. Environ Innov Soc Trans 6:9-23

Pfeiffer S (2017) The Vision of Industrie 4.0 in the Making - a case of future told, tamed, and traded. Nanoethics 11:107-121

Pittaway L, Robertson M, Munir K, Denyer D, Neely AD (2004) Networking and innovation: a systematic review of the evidence. Int J Manag Rev 5-6:137-168

Powell WW, Ginnaella E (2010) Collective invention and inventor networks, in Handbook in Economics, The economics of corporate governance, Volume 1. Elsevier, Amsterdam, pp 575-605

Powell WW, Grodal S (2005) Networks of innovations. In: Fagerberg J, Mowery DC, Nelson RR (eds) The Oxford Handbook of Innovation. Oxford University Press, Oxford

Pyka A (1997) Informal networking. Technovation 17:207-220

Pyka A, Scharnhorst A (eds) (2009) Innovation networks: new approaches in modelling and analyzing. Springer, Berlin

Richardson G (1972) The Organisation of Industry. Econ J 82:883-896

Rifkin J (2011) The Third Industrial Revolution: how lateral power is transforming energy, the economy, and the world. Palgrave Macmillan, New York

Roco MC, Bainbridge WS (2003) Converging technologies for improving human performance: nanotechnology, biotechnology, information technology, and cognitive science. Springer, Netherlands, Heidelberg

Rycroft RW, Kash DE (2004) Self-organizing innovation networks: implications for globalization. Technovation 24:187-197

Schot J, Kanger L (2018) Deep transitions: emergence, acceleration, stabilization, and directionality. Res Policy 47:1045-1059

Schumpeter JA [1912] 1934 Theorie der wirtschaftlichen Entwicklung, Leipzig, Verlag von Duncker \& Humblot. Third edition translated by R. Opie as The theory of economic development. Harvard University Press, Cambridge 
Schumpeter JA (1939) Business cycles: a theoretical, historical, and statistical analysis of the capitalist process. McGraw-Hill, New York

Schumpeter JA (1942) Capitalism, socialism and democracy. Harper and Brothers, New York

Schwab K (2016) The Fourth Industrial Revolution. World Economic Forum, Geneva

Schwab K, Davis N (2018) Shaping the future of the fourth industrial revolution. Currency, New York

Shan W, Walker G, Kogut B (1994) Interfirm cooperation and startup innovation in the biotechnology industry. Strateg Manag J 15:387-394

Simon HA (1969) 1996 The Sciences of the Artificial, Mass, 3rd edn. MIT Press, Cambridge

Smith A [1776] 1976 An inquire into the nature and causes of the wealth of nations. In: R H Campbell and A S Skinner (eds) volumes 1 and 2 of the Glasgow Edition of the Works and Correspondence of Adam Smith. Oxford University Press, Oxford

Spufford P (1988) Money and its use in medieval Europe. Cambridge University Press, Cambridge

Thomson R (2009) Structures of change in the mechanical age: technological innovation in the United States, 1790-1865. Johns Hopkins, University Press

Tidd J (2006) A review of innovation models, Discussion Paper 1. Tanaka Business School, Imperial College London, London

Tomasello MV, Napoletano M, Garas A, Schweitzer F (2016) The rise and fall of R\&D networks. Ind Corp Chang 26:1-30

von Hippel E (2007) Horizontal innovation networks - by and for users. Ind Corp Chang 16(2):293-315

von Tunzelmann GN (2004) Network Alignment in the Catching-Up Economies in Europe. In: McGowan F, Radosevic S, von Tunzelmann N (eds) The Emerging Industrial Structure of the Wider Europe. Routledge, London, pp 23-37

von Tunzelmann N (2009) Competencies versus capabilities: A reassessment. Econ Politica 3:435-464

Weiser M (1991) The computer for the 21st Century. Sci Am 265(3):94-104

Wernerfelt B (1984) A resource-based view of the firm. Strateg Manag J 5(2):171-180

Zander I (2002) The formation of international innovation networks in the multinational corporation: an evolutionary perspective. Ind Corp Chang 11(2):327-353 